\title{
Key Factors Influencing Weed Infestation of Cool-season Turfgrass Festuca arundinacea Schreb. Areas during Early Spring in the Tianjin Region, China
}

\author{
Jin-wei Zhang ${ }^{1}$ \\ National Engineering Research Center for Information Technology in \\ Agriculture, Beijing, China 100193; and Tianjin Institute of Plant \\ Protection, Tianjin, China 300384 \\ Yi-xue Liu, Jin-ping Yu, and Wei Zhang \\ Tianjin Institute of Plant Protection, Tianjin, China 300384 \\ Ya-qiong Xie \\ Beijing Nutrichem Company Limited, Beijing, China 102206 \\ Ning-ning Ge \\ Beijing Union of Farmers' Association, Beijing, China 100062
}

Additional index words. weed survey, weed community, weed dominance index, relative frequency, relative uniformity, relative abundance

\begin{abstract}
In the early Spring of 2015 and 2016, weed infestation surveys were conducted in areas of cool-season turfgrass Festuca arundinacea Schreb. at 23 sites within Tianjin municipality in northern China. The weed community within turfgrass areas comprised 37 weed species belonging to 14 families. Perennial weeds accounted for $45.9 \%$ of the total community of weed species, whereas annual or biennial weeds accounted for $54.1 \%$. Asteraceae was the dominant family $(43.2 \%)$, and the percentage of broadleaved weeds was $94.6 \%$. Statistical analyses of the weed dominance index (integrating weed relative height and relative coverage) and relative abundance (integrating weed relative density, frequency, and uniformity) showed that the 10 most common weed species during the early spring were Ixeris polycephala Cass., Taraxacum mongolicum Hand.-Mazz., Inula japonica Thunb., Hemistepta lyrata Bge., Trigonotis pedunclaris (Trev.) Benth., Calystegia hederacea Wall., Lepidium apetalum Willd., Plantago asiatica L., Cirsium segetum Bge., and Ixeris sonchifolia Hance. Ixeris polycephala Cass. and T. mongolicum Hand.-Mazz were the most dominant and harmful weed species. Partial correlation analysis (PACA) indicated that the deterioration rate (percentage of bare soil or coverage of plants other than turfgrass) of the turfgrass area was significantly and positively correlated with the total dominance index [(TDI), an index to evaluate the weed infestation severity)] and that the soil organic matter (SOM) and salinity factors were negatively correlated with the TDI. Factors such as soil nutrient conditions (the contents of $N, P$, and $K$ and the total $\mathrm{N}$ ), soil physical properties (density and clay content), soil moisture, soil temperature, and soil pH did not correlate significantly with the TDI. We conclude that the deterioration rate was the most important factor influencing weed infestation in the early spring and that SOM and soil salinity might also be important factors. The results of this study can help turfgrass researchers and managers identify the most harmful weed species and integrate management strategies in areas of cool-season turfgrass $F$. arundinacea Schreb. during early spring in the Tianjin region, China.
\end{abstract}

Accompanying the rapid promotion of urbanization in China, there is an increasing demand for recreational areas, athletic fields, and other types of functional green spaces. Lawns and turfgrasses have become ubiquitous in urban landscapes; residential, commercial, and institutional lawns; parks; athletic fields; and golf courses. They play very important roles in the daily life of people (Beard and Green, 1994), especially in economically developed regions, during the past 10 years in China (Shan et al., 2013). A current challenge in turfgrass development involves turfgrass management-although people pay considerable attention to the establishment of turfgrass areas, they pay less to their subsequent management. This inattentiveness has led to the rapid deterioration of turfgrass areas via pest infestation, anthropogenic damage, and other factors $(\mathrm{Hu}$ et al., 2001). Weed infestation is the major problem affecting turfgrass areas and is often the result of low-level turfgrass daily maintenance (Uddin et al., 2010). Turfgrass weeds include grasses, grass-like plants (rushes or sedges), and broadleaved plants and with annual, biennial, and/or perennial life cycles. Weeds compete with turfgrass plants for light, nutrients, water, and space. Some weeds are hosts for pests such as pathogens, nematodes, and insects and some are irritants to humans, causing allergic reactions through the production of pollen or chemicals (Zimdahl, 2007). Some dominant species are aggressive weeds and greatly limit turfgrass growth. Other relatively rare species increase the biodiversity in the turfgrass ecosystem. However, weeds affect the appearance, value, and health of the turfgrass landscape and contribute to its deterioration. Therefore, to maintain the health and esthetic quality of turfgrass areas, weeds must be eliminated from these areas.

The weed flora composition of a given cultured area is usually strongly dependent on the geographical region and crop species (Qiang, 2005; Streibig, 1979). Festuca arundinacea Schreb. is a very important coolseason turfgrass plant (Charles et al., 1991). It can be planted from the northeast to the Yangtze River region of China because of its high resistance to drought, flooding, saline-alkali stress, and low need for maintenance (Hu et al., 2001). In our survey, this turfgrass plant accounted for more than $95 \%$ of plants used for landscaping in the Tianjin region. Previous surveys have been conducted regarding weed infestation and distribution in areas of this turfgrass species in China (Bai et al., 2007; Cui et al., 2003; Qiang and Li, 2000; Wei et al., 1998; Wu et al., 1997; Zhao et al., 2003). These previous reports demonstrated weed infestation at certain places or times using inexact and descriptive approaches; thus, quantitative analyses of weed community composition and dominance during certain periods are lacking. The early spring is an important period before weed management practices are conducted in turfgrass areas in the Tianjin region, China. However, information regarding the weed community composition and distribution in these areas during the early spring has not been documented. This gap in knowledge has limited the development of predictive ecological risk assessments for weed encroachment and the development of strategies to manage weeds. Therefore, a detailed weed infestation survey to determine the occurrence and importance of weed species in $F$. arundinacea Schreb. turfgrass areas during the early spring would allow turfgrass researchers and managers to develop guidelines for weed management.

Environmental and anthropogenic factors such as climate change, soil conditions, and cropping system management contribute to variability in weed infestation in cropland (Nkoa et al., 2015; Qiang, 2005). Dieleman et al. (2000a, 2000b) identified associations among site properties and weed species abundance and Andersson and Milberg (1998) determined the relationships between weed flora composition and the relative importance of crop, crop rotation, and 
nitrogen. In addition, Hume (1982) and Hume et al. (1991) determined the impacts of agronomic practices on weed community composition in wheat. There have been few studies of the factors that influence weed infestation in cool-season $F$. arundinacea Schreb. turfgrass areas. Investigating weed infestation in such areas under different environmental conditions and the influencing factors can help improve weed management strategies in turfgrass areas.

The goals of this article were to a) identify the most common and dominant weed species and $b$ ) determine the factors that influence weed infestation in $F$. arundinacea Schreb. turfgrass areas during early spring in the Tianjin region by performing field surveys and quantitative analyses. The results of this study can help turfgrass researchers and managers identify the most common and harmful weed species and integrate management strategies in areas of cool-season turfgrass during early spring in this region.

\section{Materials and Methods}

Sites surveyed. Two surveys of weed infestation were conducted in mid-April of 2015 and 2016 in 23 turfgrass areas in 10 districts or counties of Tianjin, a municipality in the North China Plain. The coordinates of the 23 surveyed sites and the functions of the turfgrass areas are presented in Supplemental Table 1. Festuca arundinacea Schreb. was the turfgrass plant at most sites; at two sites, it was the dominant turfgrass plant but occurred along with Poa pratensis L. The size of the area surveyed at each site was at least $1000 \mathrm{~m}^{2}$. No fertilizer, mowing, or weed management programs had been carried out at the sites, and only some sites had been irrigated before the survey.

Data collection. The plots were selected by walking across the central areas of the turfgrass sites and throwing a sample quadrat $\left(0.25 \mathrm{~m}^{2}\right)$ in a random direction. This resulted in a total of 15 sampling locations at each site. Our methods followed those of Andreasen et al. (1996). The weed species at each sampling location were identified and recorded for further analysis. To quantify and analyze the data, weed density, uniformity, frequency, relative density, relative uniformity, and relative frequency were calculated according to the following Eqs. [1]-

\footnotetext{
Received for publication 15 Nov. 2017. Accepted for publication 21 Mar. 2018.

This research was supported by the Special Fund for Agro-scientific Research in the Public Interest (201303031) and the Key Project of Tianjin Applied Basic and Frontier Technology Research (No.14JCZDJC34300). The authors thank the Tianjin Municipal Science and Technology Commission for financial support.

${ }^{1}$ Corresponding author. E-mail: zhangjinweibeyond@ aliyun.com.
}

[4] in reference to the methods of Thomas (1985, 1991):

$\begin{aligned} \text { Uniformity }\left(\mathrm{U}_{k}\right): & \mathrm{U}_{k}=\left(\sum_{1}^{n} \sum_{1}^{5} X_{i j} / 5 n\right) \\ & \times 100,\end{aligned}$

where $\mathrm{U}_{k}$ is the field uniformity value for species $k, X_{i j}$ is the presence (1) or absence (0) of species $k$ in quadrat $j$ (a quadrat is $0.25 \mathrm{~m}^{2}$ ) in field $i$, and $n$ is the number of fields surveyed.

$$
\operatorname{Density}\left(\mathrm{D}_{k}\right): \mathrm{D}_{k}=4 \sum_{1}^{n} \sum_{1}^{15} \mathrm{D}_{i j} / 15 n \text {, }
$$

where $\mathrm{D}_{k}$ is the density of species $k$ (plants $/ \mathrm{m}^{2}$ ), $\mathrm{D}_{i j}$ is the number of plants in quadrat $j$ in field $i$, and $n$ is the number of fields surveyed.

Frequency $\left(\mathrm{F}_{k}\right): \mathrm{F}_{k}=\left(\sum_{1}^{n} \mathrm{Y}_{i} / n\right) \times 100$,

where $\mathrm{F}_{k}$ is the frequency value for species $k$ and $Y_{i}$ is the presence (1) or absence (0) of species $k$ in field $i$.

$$
\begin{aligned}
& \mathrm{RF}_{k}=\left(\begin{array}{c}
\text { frequency value of species } k \\
\text { sum of frequency values for all species }
\end{array}\right) \\
& \mathrm{RU}_{k} \quad \begin{array}{c}
\times 100 \\
=\left(\frac{\text { uniformity value of species } k}{\text { sum of uniformity values for all species }}\right) \\
\times 100
\end{array} \\
& \mathrm{RD}_{k} \quad\left(\begin{array}{c}
\text { mean density value of species } k \\
\text { sum of mean density values for all species }
\end{array}\right) \\
& \quad \begin{array}{c}
\times 100 \\
\mathrm{RA}_{k}=\mathrm{RF}_{k}+\mathrm{RU}_{k}+\mathrm{RD}_{k},
\end{array}
\end{aligned}
$$

where $\mathrm{RF}_{k}, \mathrm{RU}_{k}$, and $\mathrm{RD}_{k}$ are the relative frequency, uniformity, and density of species $k$, respectively, and $\mathrm{RA}_{k}$ is the relative abundance of species $k$.

The severity of weed infestation in cropland depends not only on the abundance of the weeds but also on the weed coverage and height. To determine the dominance of different weed species in the weed community, two indexes, the dominance index (the product of the relative height of a weed to the turfgrass plant, scaling 0 to 1 , and the relative coverage of that weed in a quadrat, scaling $0 \%$ to $100 \%$, DI) and the percentage of dominance index (PDI) were used according to Eqs. [5] and [6] following the methods of Wu et al. (1997) and Zhou et al. (2004):

$$
\mathrm{DI}_{k}=\mathrm{RH}_{k} \times \mathrm{RC}_{k} \times 100,
$$

where $\mathrm{DI}_{k}$ is the dominance index of species $k, \mathrm{RH}_{k}$ is the relative height to the turfgrass plant of species $k$, and $\mathrm{RC}_{k}$ is the relative coverage in the quadrat of species $k$.

$\mathrm{PDI}_{k}$
$=\left(\frac{\text { DI value of species } k}{\text { sum of DI values of all species }}\right) \times 100$,

where $\mathrm{PDI}_{k}$ is the PDI value of species $k$. A weed species was defined as a dominant weed when PDI $\geq 10 \%$, as an important weed when $1 \% \leq \mathrm{PDI}<10 \%$, and as a subdominant weed when PDI $<1 \%$.
Soil nutrient conditions (the contents of total nitrogen, hydrolyzable nitrogen, rapidly available phosphorus, rapidly available potassium, and organic matter) and soil physical properties (clay content and soil density) for the 0 - to $25-\mathrm{cm}$ soil layer were analyzed by the Tianjin Institute of Resource and Environmental Science. At sampling, the soil temperature of the $0-$ to $18-\mathrm{cm}$ layer was measured with a digital probe thermometer (Kat. Nr. 30.1021; TFA Dostmann GmbH \& Co. KG, Wertheim-Reicholzheim, Germany). The soil salinity of the 0 - to $18-\mathrm{cm}$ layer and the soil $\mathrm{pH}$ at the $0-$ to $11-\mathrm{cm}$ layer were measured with PNT3000 and pH3000 m, respectively (STEP Systems GmbH, Nürnberg, Germany). The soil moisture of the 0 - to $18-\mathrm{cm}$ layer was measured with a Field Scout TDR 100 system (Item\# 6440FS, Spectrum ${ }^{\circledR}$ Technologies, Inc., Aurora, IL). The soil moisture data consisted of mass water content in 2015 and volumetric water content in 2016. Except for soil temperature and soil moisture (measured and analyzed separately in 2 years as two repetitions), the soil variables were measured in 2015 alone because they were not expected to change drastically in two successive years (Supplemental Table 1). Visual estimation of turfgrass deterioration was conducted during the survey. Deterioration ratings were based on a scale from $0 \%$ to $100 \%$ (where $0 \%=$ no turfgrass deterioration and complete coverage of the ground by turfgrass plants and $100 \%=$ severe turfgrass deterioration and either completely barren ground or groundcovered by other plants).

Statistical analysis. Total weed density (TWD) and TDI (the sum of DI value that is the product of relative height and the relative coverage of each weed species) of all weed species in a $0.25-\mathrm{m}^{2}$ quadrat of each survey sites were calculated. To determine the correlations between the factors that might influence weed infestation and TDI in the turfgrass sites, PACA was performed using the software SPSS 19.0 (SPSS, Inc., Chicago, IL). Correlations between TDI and each of the 12 potential influencing factors (the abovementioned soil nutrient conditions, soil physical properties, temperature, moisture, salinity, $\mathrm{pH}$, and turfgrass deterioration) for each survey site were calculated. PACA was used to determine the correlation between TDI and each of the 12 factors holding the effects of the remaining factors constant. Pearson correlation analysis was used to evaluate the correlation between two variables and twotailed $P$ values were calculated to indicate the significance at $\alpha=0.05$. Factors that were significantly correlated with TDI have influence on weed infestation. The data from 2015 and 2016 were analyzed separately because significant interactions of year with TDI, soil moisture, and other variables were found.

\section{Results}

Weed community composition. Across all turfgrass sites surveyed during early spring in both years, 37 weed species belonging to 14 
different families were identified; these species are presented in alphabetic order in Supplemental Table 2. When classifying each weed according to life cycle, there were 17 perennial weeds, accounting for $45.9 \%$ of all of the weed species, and 20 annual or biennial weeds, accounting for $54.1 \%$ of the weed species. Asteraceae (16 species) and Brassicaceae (five species) were the dominant weed families, representing $43.2 \%$ and $13.5 \%$ of the weed species, respectively. When classified from the point of weed management, there were 35 broadleaved weed species and two grass weed species, accounting for $94.6 \%$ and $5.4 \%$ of the weed species, respectively.

Weed dominance analysis. To quantify the dominance of each weed species surveyed across all sites over 2 years, the relative abundance value of each weed species (incorporating weed density, distribution uniformity, and frequency parameters) was calculated. The results from both years indicated that I. polycephala Cass., T. mongolicum Hand.-Mazz., I. japonica Thunb., $H$. lyrata Bge., T. pedunclaris (Trev.) Benth., C. hederacea Wall, L. apetalum Willd., P. asiatica L., Circus segetum Bge., and I. sonchifolia Hance. were the 10 most abundant weed species during the early spring, although their rank order slightly differed between the 2 years. All 10 weed species were broadleaved weeds and they belonged to five families: Asteraceae (six species), Boraginaceae, Brassicaceae, Plantaginaceae, and Convolvulaceae (one species each) (Tables 1 and 2).

In addition to relative abundance, the PDI of each weed (integrating weed coverage and height) was calculated to reflect the dominance of each weed in the community. The results indicated that I. polycephala Cass. and T. mongolicum Hand.-Mazz. were the two dominant weed species, with PDI values above $10 \%$ in both years.

Weed infestation variability and key influencing factors. For each site, the TWD and TDI were calculated, and the dominant weed species were identified and summarized to identify the weed community and the differences in infestation severity among sites. The severity of weed infestation varied widely in both years. Both TWD and TDI were low at some survey sites (e.g., Chaoyang Avenue and Jingjin New City) and high at others (e.g., Jixian County and Xiaodian Park). The dominant weed species differed among the 23 survey sites and some were not among the 10 most common weed species at each site (Table 3 ).

Correlations between TDI and each of the 12 factors (including the soil nutrient conditions, soil properties, temperature, moisture, salinity, $\mathrm{pH}$, and turfgrass deterioration) potentially related to weed infestation of turfgrass at each site were analyzed by PACA. The results indicated that the deterioration rate (D) of a turfgrass area was significantly and positively correlated with TDI $(P=0.001$ in 2015 and $P=0.004$ in 2016, with a partial correlation coefficient of 0.8238 in 2015 and 0.7648 in 2016) in both years. Soil organic matter and soil salinity (S) were negatively correlated with TDI, and the correlations were significant in $2015(P<0.05)$. However, no significant correlation between TDI and the remaining nine factors was observed in either year (Table 4).

\section{Discussion}

Weed community composition. When weeds appear in a crop production system, identification of the weed community composition is required before economical and effective management practices can be undertaken (Frick and Thomas, 1992; McCully et al., 1991; Thomas, 1985, 1991). The results of our survey indicated that perennial and biennial broadleaved weed species belonging to the families Asteraceae and Brassicaceae are the weeds to target during early spring in the Tianjin region, China. Severely harmful annual weed species, e.g., large crabgrass [Digitaria sanguinalis (L.) Scop.] and small crabgrass (Digitaria ischaemum Schreb. ex Muhl.) had not infested by mid-April in this region. The absence of these species might be due to unsuitable environmental conditions for weed infestation (e.g., the combination of soil temperature and moisture) during this period (Masin et al., 2005).

Festuca arundinacea Schreb., as a popular cool-season turfgrass plant, is planted extensively in large areas of China. The present findings of weed community composition in turfgrass areas during the early spring in Tianjin, a typical region of the North China Plain, are of broad interest to turfgrass researchers and managers from other regions where $F$. arundinacea Schreb. is planted.

Common and dominant weed species. Weed density, frequency, uniformity, and their relative values to the whole community are commonly used parameters to analyze weed composition in crop production systems. However, each parameter has limitations when used independently because it might not accurately reflect the ecological importance of a species within a community (Andreasen and Stryhn, 2008; Nkoa et al., 2015; Thomas, 1985; Uddin et al., 2010). Hence, we integrated weed density, field frequency, and field uniformity into relative

Table 1. The 10 most common weed species in areas of Festuca arundinacea Schreb. turfgrass during the early Spring of 2015.

\begin{tabular}{|c|c|c|c|c|c|c|c|c|}
\hline Weed species & Uniformity (\%) & $\begin{array}{c}\text { Density } \\
\left(\text { plant } / \mathrm{m}^{2}\right)\end{array}$ & Frequency $(\%)$ & $\begin{array}{c}\text { Relative } \\
\text { uniformity (\%) }\end{array}$ & $\begin{array}{c}\text { Relative } \\
\text { density (\%) }\end{array}$ & $\begin{array}{c}\text { Relative } \\
\text { frequency }(\%)\end{array}$ & $\begin{array}{c}\text { Relative } \\
\text { abundance (\%) }\end{array}$ & PDI (\%) \\
\hline Trigonotis pedunclaris (Trev.) Benth. & 19.42 & 20.74 & 60.87 & 11.70 & 45.89 & 8.43 & 66.02 & 8.06 \\
\hline Ixeris polycephala Cass. & 44.93 & 8.61 & 100.00 & 27.06 & 19.06 & 13.85 & 59.97 & 24.70 \\
\hline Taraxacum mongolicum Hand.-Mazz. & 16.52 & 1.17 & 69.57 & 9.95 & 2.59 & 9.64 & 22.18 & 13.06 \\
\hline Inula japonica Thunb. & 11.59 & 4.48 & 34.78 & 6.98 & 9.90 & 4.82 & 21.70 & 5.89 \\
\hline Hemistepta lyrata Bge. & 9.86 & 0.56 & 60.87 & 5.94 & 1.23 & 8.43 & 15.60 & 6.36 \\
\hline Lepidium apetalum Willd. & 10.14 & 1.98 & 34.78 & 6.11 & 4.39 & 4.82 & 15.32 & 7.71 \\
\hline Plantago asiatica $\mathrm{L}$. & 10.14 & 0.72 & 47.83 & 6.11 & 1.59 & 6.62 & 14.33 & 4.42 \\
\hline Calystegia hederacea Wall. & 6.09 & 0.53 & 34.78 & 3.67 & 1.18 & 4.82 & 9.66 & 2.40 \\
\hline Cirsium segetum Bge. & 3.48 & 0.35 & 21.74 & 3.10 & 0.77 & 4.01 & 7.88 & 3.31 \\
\hline Ixeris sonchifolia Hance. & 2.61 & 0.14 & 21.74 & 1.57 & 1.31 & 4.01 & 6.89 & 3.77 \\
\hline
\end{tabular}

PDI $=$ percentage of dominance value of the weed species.

Table 2. The 10 most common weed species in areas of Festuca arundinacea Schreb. turfgrass during the early Spring of 2016.

\begin{tabular}{|c|c|c|c|c|c|c|c|c|}
\hline Weed species & Uniformity (\%) & $\begin{array}{c}\text { Density } \\
\left(\text { plant } / \mathrm{m}^{2}\right)\end{array}$ & Frequency $(\%)$ & $\begin{array}{c}\text { Relative } \\
\text { uniformity (\%) }\end{array}$ & $\begin{array}{c}\text { Relative } \\
\text { density (\%) }\end{array}$ & $\begin{array}{c}\text { Relative } \\
\text { frequency }(\%)\end{array}$ & $\begin{array}{c}\text { Relative } \\
\text { abundance (\%) }\end{array}$ & PDI $(\%)$ \\
\hline Ixeris polycephala Cass. & 39.86 & 4.36 & 91.30 & 23.75 & 16.78 & 11.80 & 52.33 & 19.07 \\
\hline Trigonotis pedunclaris (Trev.) Benth. & 15.58 & 6.99 & 52.17 & 9.28 & 26.87 & 6.74 & 42.89 & 6.18 \\
\hline Taraxacum mongolicum Hand.-Mazz. & 21.74 & 1.57 & 73.91 & 12.96 & 6.02 & 9.55 & 28.52 & 18.13 \\
\hline Inula japonica Thunb. & 10.14 & 3.48 & 43.48 & 6.05 & 13.38 & 5.62 & 25.04 & 3.17 \\
\hline Hemistepta lyrata Bge. & 10.87 & 0.64 & 60.87 & 6.48 & 2.45 & 7.86 & 16.79 & 5.16 \\
\hline Calystegia hederacea Wall. & 10.14 & 1.17 & 43.48 & 6.05 & 4.52 & 5.62 & 16.18 & 3.41 \\
\hline Plantago asiatica $\mathrm{L}$ & 8.33 & 0.65 & 52.17 & 4.97 & 2.51 & 6.74 & 14.22 & 2.85 \\
\hline Lepidium apetalum Willd. & 6.52 & 1.10 & 30.43 & 3.89 & 4.24 & 3.93 & 12.06 & 8.16 \\
\hline Ixeris sonchifolia Hance. & 6.16 & 0.64 & 21.74 & 4.67 & 2.45 & 4.61 & 11.73 & 6.13 \\
\hline Cirsium segetum Bge. & 5.43 & 0.64 & 26.09 & 3.24 & 2.45 & 3.37 & 9.06 & 2.95 \\
\hline
\end{tabular}

$\mathrm{PDI}=$ percentage of dominance value of the weed species. 


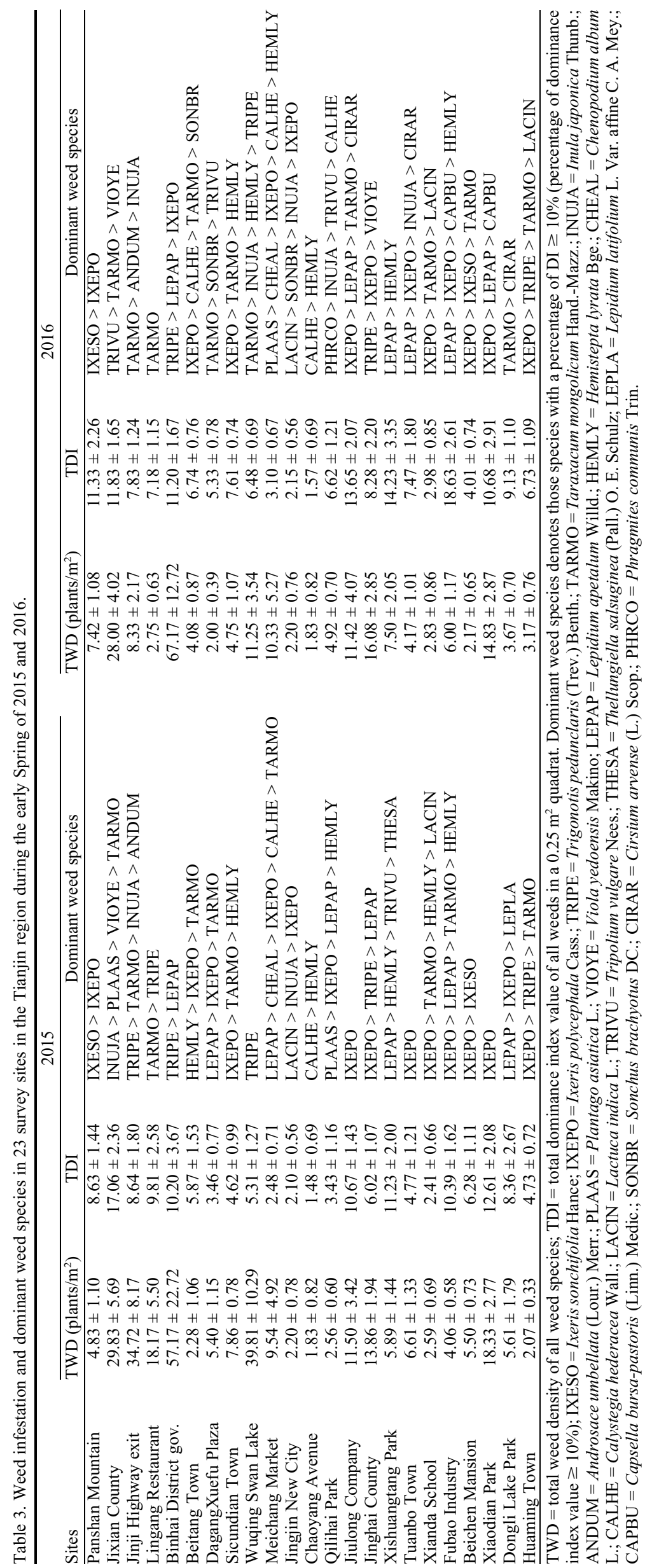


Table 4. Partial correlation analysis results of weed infestation and 12 related factors in the Tianjin region during the early Spring of 2015 and 2016.

\begin{tabular}{|c|c|c|c|c|}
\hline \multirow[b]{2}{*}{ Factor } & \multicolumn{2}{|l|}{2015} & \multicolumn{2}{|l|}{$\begin{array}{r}2016 \\
\end{array}$} \\
\hline & Partial correlation coefficient & $P$ value & Partial correlation coefficient & $P$ value \\
\hline$\overline{\mathrm{CP}}$ & 0.2964 & 0.350 & 0.1330 & 0.680 \\
\hline SD & -0.0679 & 0.834 & -0.0518 & 0.873 \\
\hline $\mathrm{TN}$ & 0.5188 & 0.084 & 0.3718 & 0.234 \\
\hline $\mathrm{N}$ & -0.1653 & 0.608 & -0.3583 & 0.253 \\
\hline $\mathrm{P}$ & -0.1328 & 0.681 & 0.3404 & 0.279 \\
\hline $\mathrm{K}$ & -0.0846 & 0.794 & -0.1778 & 0.580 \\
\hline SOM & -0.6269 & $0.039^{z}$ & -0.4279 & 0.165 \\
\hline S & -0.5919 & $0.043^{z}$ & -0.4071 & 0.189 \\
\hline $\mathrm{pH}$ & 0.1388 & 0.667 & 0.3376 & 0.283 \\
\hline $\mathrm{D}$ & 0.8238 & $0.001^{z}$ & 0.7648 & $0.004^{z}$ \\
\hline SM & -0.3461 & 0.270 & 0.2225 & 0.487 \\
\hline ST & 0.0086 & 0.979 & 0.2088 & 0.515 \\
\hline
\end{tabular}

${ }^{\mathrm{z}}$ Denotes that the correlation was significant at $\alpha=0.05$.

$\mathrm{DI}=$ product of the relative height and the relative coverage value of a weed in a quadrat; $\mathrm{CP}=$ clay conten percentage of the soil; $\mathrm{SD}=$ soil density; $\mathrm{TN}=$ total nitrogen content of the soil; $\mathrm{N}=$ hydrolyzable nitrogen; $\mathrm{P}=$ rapidly available phosphorus; $\mathrm{K}=$ rapidly available potassium; $\mathrm{SOM}=$ soil organic matter; $\mathrm{S}=$ salinity content of the soil; $\mathrm{D}=$ deterioration rate of the turfgrass (on a scale from $0 \%$ to $100 \%$ ); $\mathrm{SM}=$ soil moisture; $\mathrm{ST}=$ soil temperature at a depth of $0-18 \mathrm{~cm}$.

abundance, and we integrated relative height and coverage into PDI for each weed species. The top 10 weed species ranked according to PDI value were the same as those ranked according to relative abundance value (Tables 1 and 2). This demonstrated that these two parameters are appropriate for determining the severely infesting weed species, and our ranking of the 10 most common weed species we identified during this period in this region is highly credible.

Based on the analyses of PDI for the 2 years, I. polycephala Cass. and T. mongolicum Hand-Mazz. were identified as the two dominant weed species. Esmaili and Salehi (2009) and Ferguson et al. (2016) reported that Taraxacum officinale is problematic for turfgrass managers each year, and this plant strongly competes with turfgrass plants for resources (Franssen and Kells, 2007). Although T. mongolicum Hand-Mazz. is a different species from the congeneric $T$. officinale and although there are few reports on I. polycephala Cass infestation of turfgrass areas, infestation by the two weed species identified here warrants attention.

Key factors influencing weed infestation. Weed populations in turfgrass areas are governed by both ecological and human activities, and the interactions that invariably occur between weed species and environmental or management variables are very complex (Nkoa et al., 2015). According to the PACA in our study, the deterioration rate of turfgrass was significantly and positively correlated with TDI in both years. Most of the turfgrass areas with high deterioration rates were severely infested by weeds and located in residential areas (e.g., Xishuangtang Park and Xiaodian Park). This observation is consistent with the results of Uddin et al. (2010), who demonstrated that residential lawns had more weeds than did golf course putting greens, athletic fields, and sod farms. High daily foot traffic, low daily maintenance, and aged turfgrass plants are likely reasons for this phenomenon. Soil organic matter typically influences weed abundance in the field (Dieleman et al., 2000a, 2000b; Medlin et al., 2001). The negative correlation observed between SOM and TDI in our study might be due to the positive effects of high SOM on turfgrass growth. It precludes severe weed invasion and establishment. Similar to SOM, soil salinity showed a negative correlation with TDI (e.g., the soil salinity at the Chaoyang Avenue site was high, but the weed infestation severity was low). This result might be due to inhibitory effects of high soil salinity on the growth of most of the weed species and the subsequent reduction of the weed infestation of turfgrass. No significant correlation between TDI and any of the remaining nine parameters was observed; it is possible that the differences in these parameters among the different turfgrass areas were too small to be detected statistically.

Our 2-year survey identified the 10 most common and the two most harmful weed species in $F$. arundinacea Schreb. turfgrass areas and the three key factors (turfgrass deterioration rate, SOM and salinity) influencing weed infestation of these areas during early spring in the Tianjin region, China. These findings allow turfgrass researchers and managers to target specific harmful weed species. In addition, they can improve the development of preventive and curative weed management programs and promote precise and efficient weed control. By understanding the key factors that influence weed infestation, nonchemical strategies to control harmful weeds can be adopted, such as optimizing daily turfgrass maintenance (e.g., mowing, irrigation, fertilization, and other practices), restoring areas of turfgrass deterioration and controlling weeds by using saline water (see Uddin et al., 2014).

\section{Literature Cited}

Andersson, T.N. and P. Milberg. 1998. Weed flora and the relative importance of site, crop, crop rotation, and nitrogen. Weed Sci. 46:30-38.

Andreasen, C. and H. Stryhn. 2008. Increasing weed flora in Danish arable fields and its importance for biodiversity. Weed Res. 48(1):1-9.
Andreasen, C., H. Stryhn, and J.C. Streibig. 1996. Decline of the flora in Danish arable fields. J. Appl. Ecol. 33:619-626.

Bai, Y., S. Wei, D. Liu, X. Yin, B. Liu, and Z. He. 2007. A preliminary survey report of weeds in turf of Liaoning Province (Chinese). Weed Sci. 2007(2):38-39.

Beard, J.B. and R.L. Green. 1994. The role of turfgrasses in environmental protection and their benefits to humans. J. Environ. Qual. 23(3): 452-460.

Charles, G.W., G.J. Blair, and A.C. Andrews. 1991. The effect of sowing time, sowing technique and post-sowing weed competition on tall fescue (Festuca arundinacea Schreb.) seedling establishment. Austral. J. Agr. Res. 42(7): 1251-1259.

Cui, Y., Z. Li, Y. Ren, M. Yue, and Y. Zhang. 2003. Weed occurrence and succession in the cool seasonal turfgrass (Chinese). J. Chi. Ecol. 22(2):20-23.

Dieleman, J.A., D.A. Mortensen, D.D. Buhler, C.A. Cambardella, and T.B. Moorman. 2000a. Identifying associations among site properties and weed species abundance. I. Multivariate analysis. Weed Sci. 48(5): 567-575.

Dieleman, J.A., D.A. Mortensen, D.D. Buhler, and R.B. Ferguson. 2000b. Identifying associations among site properties and weed species abundance. II. Hypothesis generation. Weed Sci. 48(5):576-587.

Esmaili, S. and H. Salehi. 2009. Floristic composition of weed community in turfgrass field of BaggahIran. Iran J. Weed Sci. 5:55-64.

Ferguson, J.C., R.E. Gaussoin, J.A. Eastin, M.D. Sousek, and G.R. Kruger. 2016. Efficacy of pre and post emergence herbicides on weed suppression in established turfgrass with a conventional and an ultra-low volume sprayer. Crop Protection 89:72-77.

Franssen, A.S. and J.J. Kells. 2007. Common dandelion (Taraxacum officinale) control with postemergence herbicides in no-tillage glufosinateresistant corn. Weed Technol. 21(1):14-17.

Frick, B. and A.G. Thomas. 1992. Weed surveys in different tillage systems in southwestern Ontario field crops. Can. J. Plant Sci. 72(4): 1337-1347.

Hu, L., X. Bian, and X. Yang. 2001. Turfgrass science and management (Chinese). China Agr. Univ. Press, Beijing, China.

Hume, L. 1982. The long-term effects of fertilizer application and three rotations on weed communities in wheat (after 21-22 years at Indian Head, Saskatchewan). Can. J. Plant Sci. 62(3):741-750.

Hume, L., S. Tessier, and F.B. Dyck. 1991. Tillage and rotation influences on weed community composition in wheat (Triticum aestivum L.) in southwestern Saskatchewan. Can. J. Plant Sci. 71(3):783-789.

Institute for the Control of Agrochemicals and Ministry of Agriculture and The Japanese Association for the Study of Plant Regulator. 2000. Chinese colored weed illustrated book. Natl. Assn. Rural Educ. Chinese Educ. Soc. Press, Shijiazhuang, China.

Masin, R., M.C. Zuin, D.W. Archer, F. Forcella, and G. Zanin. 2005. WeedTurf: A predictive model to aid control of annual summer weeds in turf. Weed Sci. 53(2):193-201.

McCully, K.V., M.G. Sampson, and A.K. Watson. 1991. Weed survey of Nova Scotia lowbush blueberry (Vaccinium angustifolium) fields. Weed Sci. 1991:180-185.

Medlin, C.R., D.R. Shaw, M.S. Cox, P.D. Gerard, M.J. Abshire, and M.C. Wardlaw, III. 2001. 
Using soil parameters to predict weed infestations in soybean. Weed Sci. 49(3):367-374.

Nkoa, R., M.D. Owen, and C.J. Swanton. 2015. Weed abundance, distribution, diversity, and community analyses. Weed Sci. 63(sp1): 64-90.

Qiang, S. 2005. Multivariate analysis, description, and ecological interpretation of weed vegetation in the summer crop fields of Anhui Province, China. J. Integr. Plant Biol. 47(10): 1193-1210.

Qiang, S. and G. Li. 2000. Occurence of summer weed species in the turf in Nanjing city and their control (Chinese). Acta Prataculturae Sinica 9(1):48-54.

Shan, H., M.L. Li, Y. Sun, and H. Zhou. 2013. Recent development of turf grass industry in China (Chinese). Acta Agrestia Sinica 21(2): 222-229.
Streibig, J.C. 1979. Numerical methods illustrating the phytosociology of crops in relation to weed flora. J. Appl. Ecol. 1979:577-587.

Thomas, A.G. 1985. Weed survey system used in Saskatchewan for cereal and oilseed crops. Weed Sci. 1985:34-43.

Thomas, A.G. 1991. Floristic composition and relative abundance of weeds in annual crops of Manitoba. Can. J. Plant Sci. 71(3):831-839.

Uddin, M.K., A.S. Juraimi, M.R. Ismail, and J.T. Brosnan. 2010. Characterizing weed populations in different turfgrass sites throughout the Klang Valley of Western Peninsular Malaysia. Weed Technol. 24(2):173-181.

Uddin, M.K., A.S. Juraimi, M.R. Ismail, R. Othman, M.S. Ahmad-Hamdani, and A.A. Rahim. 2014 Seawater: An alternative grassy weed control method for post emergence herbicides in tropical turfgrass. Pak. J. Agr. Sci. 51(1):153-160.
Wei, X., H. Dan, Y. Chen, L. Tang, Z. Zhu, and M. Wang. 1998. Preliminary report on weeds investigation in Tianjin city. (Chinese). Tianjin Agr. Sci. 4(2):49-52.

Wu, J., G. Jiang, and C. Jia. 1997. Weediness of turf and its chemical control in Beijing area (Chinese). Acta Agr. Boreali-Sinicia 12(2): 125-130.

Zhao, L., Y. Wang, and Y. Liu. 2003. A primary analysis of ecological characters of lawn weeds in the city of hohhot (Chinese). Acta Sci. Nat. Univ. NeiMonggol (Natural Science Edition) 35(3):281-285.

Zhou, Q., H. Zhou, and T. Li. 2004. Turf weed species in north Hunan and their distribution and harm (Chinese). Pratacult. Sci. 21(3): 59-62.

Zimdahl, R.L. 2007. Fundamentals of weed science. Academic Press, Burlington, MA 


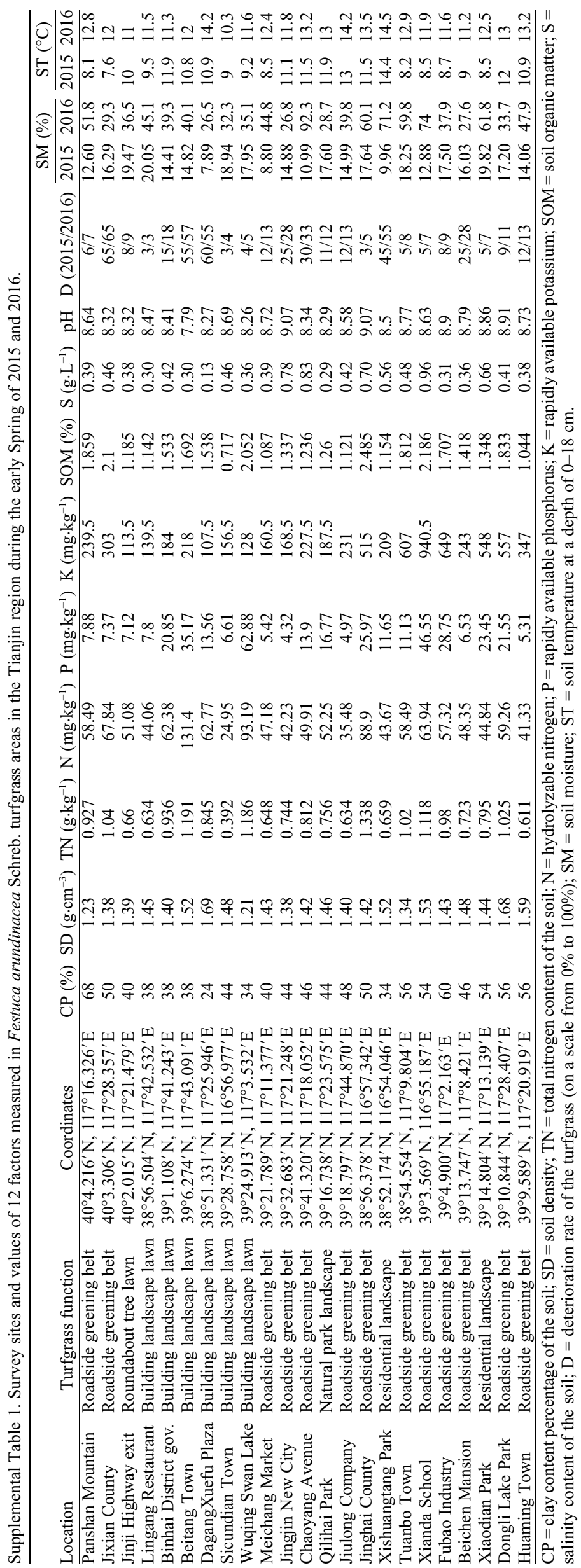


Supplemental Table 2. Alphabetical list of weed species found in Festuca arundinacea Schreb. turfgrass areas in the Tianjin region during the early Spring of 2015 and 2016.

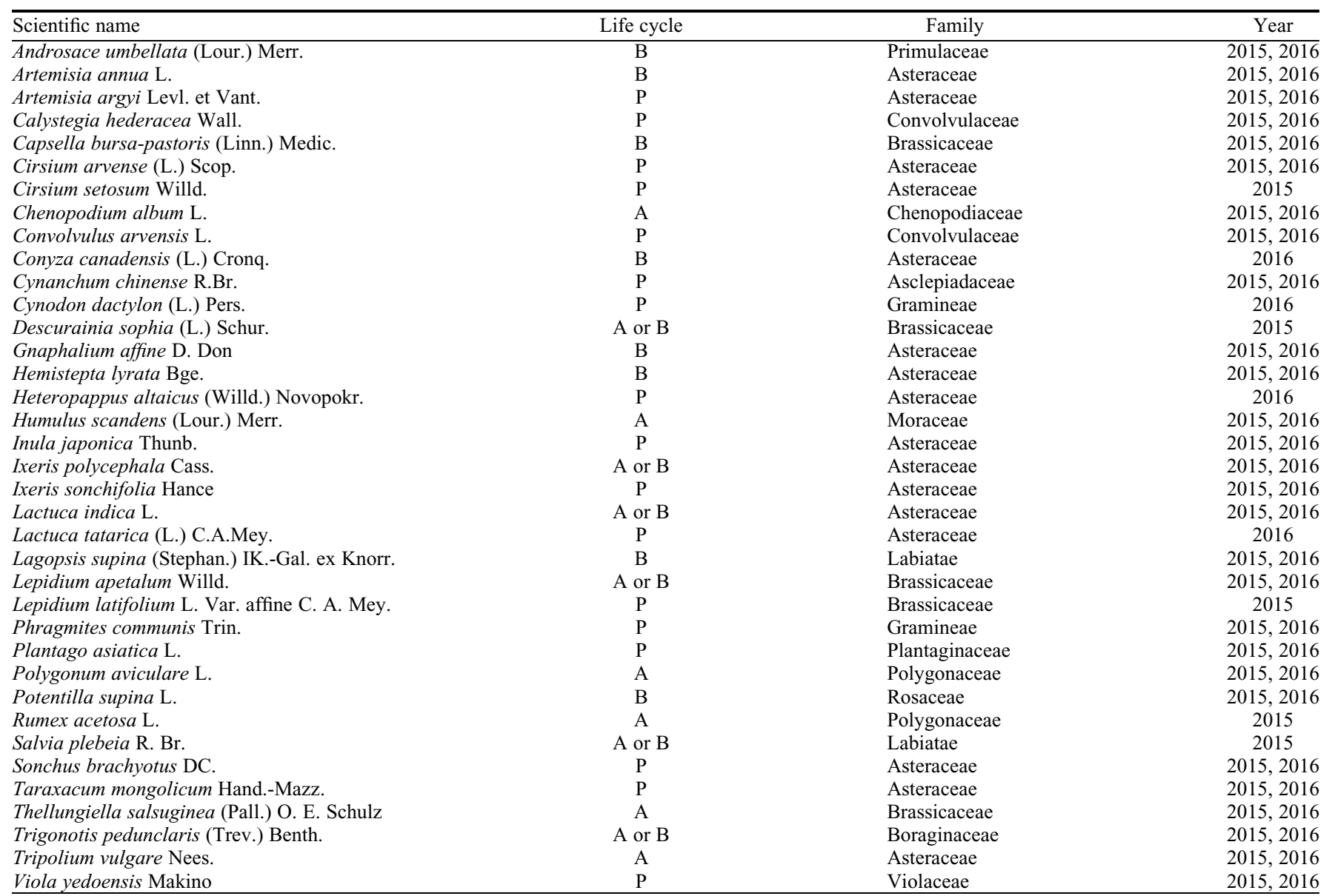

$\mathrm{A}=$ annual; $\mathrm{B}=$ biennial; $\mathrm{P}=$ perennial; $\mathrm{A}$ or $\mathrm{B}=$ annual or biennial. All of the information on the weed species was obtained from the Chinese colored weed illustrated book (Institute for the Control of Agrochemicals and Ministry of Agriculture and The Japanese Association for the Study of Plant Regulator, 2000). 